\title{
LRP1 Gene
}

National Cancer Institute

\section{Source}

National Cancer Institute. LRP1 Gene. NCI Thesaurus. Code C95472.

This gene is involved in the regulation of endocytosis. 